\title{
Core Inflation: A Review of Some Conceptual Issues
}

Mark A. Wynne

\begin{abstract}
This paper reviews various approaches to the measurement of core inflation that have been proposed over the years using the stochastic approach to index numbers as a unifying framework. It begins with a review of how the concept of core inflation is used by the world's major central banks, including some of the inflation-targeting central banks. The author provides a comprehensive review of many of the measures of core inflation that have been developed over the years and highlights some of the conceptual and practical problems associated with them. (JEL E31, C43)
\end{abstract}

Federal Reserve Bank of St. Louis Review, May/June 2008, 90(3, Part 2), pp. 205-28.

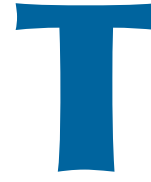

he notion of core inflation has played an important role in the deliberations of monetary policymakers for the past 25 years. However, despite the central role of this concept, there is still no consensus on how best to go about measuring core inflation. The most elementary approach, and the one that is probably the most widely used, consists of simply excluding certain categories of prices from the overall inflation rate. This is the so-called "ex. food and energy" approach to core inflation measurement, and it reflects the origin of the concept of core inflation in the turbulent decade of the 1970s. More recently, however, there has been a number of attempts to put the measurement of core inflation on a more solid statistical and theoretical footing. The newer approaches have two key features in common: First, they adopt a more statistical rather than behavioral (e.g., cost of living) approach to the problem of price measurement. And second, they invoke an alternative, monetary concept of inflation, as opposed to the traditional microeconomic costof-living concept as the guiding theory.
In this paper I critically review various approaches to measuring core inflation by linking these approaches in a single theoretical framework, the so-called stochastic approach to index numbers. I evaluate the competing merits of the different approaches and argue that a common shortcoming is the absence of a well-formulated theory of what these measures of inflation are supposed to be capturing. The notion that they somehow better capture the "monetary" component of inflation, or the component of inflation that ought to be of primary concern to central bankers, is questionable.

\section{THE CONCEPT OF CORE INFLATION}

Implicit in all discussions of core inflation is the idea that this type of inflation is fundamentally different from changes in the cost of living. The theory of the cost-of-living index is by far the most well-developed and coherent framework for infla-

Mark A. Wynne is a vice president and senior economist at the Federal Reserve Bank of Dallas and the first director of the Bank's Globalization and Monetary Policy Institute. This paper is a revised version of European Central Bank Working Paper No. 5 (Wynne, 1999). The author thanks Steve Cecchetti, Vítor Gaspar, David Lebow, Fabio Scacciavillani, seminar participants at the ECB, and an anonymous referee for comments. The author's thinking on the issue of core inflation has evolved somewhat since the first draft of this paper almost a decade ago. (See Wynne, 2008.)

(C) 2008, The Federal Reserve Bank of St. Louis. The views expressed in this article are those of the author(s) and do not necessarily reflect the views of the Federal Reserve System, the Board of Governors, the regional Federal Reserve Banks, the European Central Bank, or the European System of Central Banks. Articles may be reprinted, reproduced, published, distributed, displayed, and transmitted in their entirety if copyright notice, author name(s), and full citation are included. Abstracts, synopses, and other derivative works may be made only with prior written permission of the Federal Reserve Bank of St. Louis. 
tion measurement that currently exists: The basic theory takes as its point of departure the expenditure or cost function of a representative household at a given point in time. The change in the cost of living between some base period, 0 , and some subsequent comparison period, 1 , is then defined as the change in the minimum cost of attaining the reference utility level, $u$, between the two periods. This theory, appropriately elaborated, forms the framework for the design of the consumer price index (CPI) in the United States. However, the theory of the cost-of-living index is not the theoretical framework for the harmonized index of consumer prices (HICP) that is used to assess inflation developments in the euro area: At the time of this writing, there is no fully articulated theoretical framework for the HICP, although there is a relatively well-defined price concept, namely, "final household monetary consumption." By eschewing the use of the cost-ofliving concept, Eurostat (the statistical office of the European Community) can legitimately motivate the exclusion of certain categories of prices from the HICP. The category that has attracted the most attention by its omission is the cost of owneroccupied housing. In the U.S. CPI, for example, the cost of owner-occupied housing is measured on a rental equivalent basis, which is appropriate given the cost-of-living concept that underlies the U.S. CPI. That is, what is priced each month is not the cost of purchasing a home for owner occupancy, but rather the cost of the flow of services consumed each month, which can be proxied by the rental rates on similar housing unites (see U.S. Department of Labor, Bureau of Labor Statistics, 1997). Since the rental equivalence cost of consuming housing services each month is not part of household monetary consumption, it is not priced as part of the HICP. However, the net acquisition costs of new dwellings are arguably part of such consumption, and Eurostat is at present investigating ways of including such costs in the HICP (see Commission of the European Communities, 1998).

One common measure of core inflation excludes the effects of changes in indirect taxes from the overall inflation rate. Donkers et al. (1983) discuss how this is done in a number of
European countries. This type of measure is potentially of interest from a monetary policy perspective because, arguably, an acceleration in headline inflation that is in some sense attributable to an increase in indirect taxes ought not to be of concern to the central bank. Current practice, as reviewed by Donkers et al., is to employ various ad hoc methods to derive an estimate of the inflation rate net of indirect taxes. The exact methods employed differ from country to country. One approach is to (i) simply assume that all of the observed price change reflects the change in the tax and (ii) calculate an alternative CPI on the basis of this assumption. ${ }^{1}$ The problem with this approach is that the implicit assumption about supply elasticities (perfectly elastic) is unlikely to be a good approximation of reality for many products. A more sophisticated approach might allow for the effects of a change in indirect tax rates on the structure of production prices, but the variant analyzed by Diewert and Bossons (1987) still requires restrictive assumptions about the invariance of the input-output structure of the economy to changes in indirect tax rates.

These calculations raise the question of what it is we want a core inflation statistic to measure. If the object we are pursuing is a true cost-of-living index, then it is not clear that we should be eliminating the effects of tax increases from our price measure. Furthermore, the reasoning above is only partial equilibrium. A proper treatment of the effects of indirect taxes on a measure of the price level would require a detailed general equilibrium analysis of the effects of the tax increase that would go well beyond current practice. ${ }^{2}$ Diewert and Fox (1998) suggest a method for handling tax changes for the purposes of using inflation measures to make welfare comparisons. ${ }^{3}$

\footnotetext{
1 For details see, for example, Diewert and Bossons (1987).

2 Diewert (1997) notes that "there is no unambiguous, completely accurate method for removing all indirect commodity taxes...any attempt to do this will be a complex exercise in applied generalequilibrium modelling rather than in economic measurement. Moreover, the fact that the government has caused consumer prices to increase rather than some other economic phenomenon seems somewhat immaterial: In either case, households are facing higher prices, and we may want to measure this fact!” (Diewert, 1997, p. 134).

3 See also Diewert and Bossons (1987).
} 
Note also that in principle the distortionary effect of large infrequent changes in indirect taxes on the inflation signal may be adequately handled by some or all of the approaches reviewed below. Indirect tax changes that apply to some commodities but not others would be reflected in large price changes for the commodities in question. Limited-influence estimators of core inflation of the sort proposed by Bryan and Pike (1991) and Bryan and Cecchetti (1994) would omit these observations from the calculation of inflation. However, large changes in relative prices induced by changes in indirect taxes are arguably different from large changes that are due to other factors, such as supply or demand developments in the markets for specific goods or services. These other factors may be more difficult to identify than changes in indirect tax rates, and thus it may be more difficult to filter out their effects on the overall inflation rate.

The common point of departure for almost all analyses of core inflation is the idea that there is a well-defined concept of monetary inflation that ought to be of concern to monetary policymakers and that this type of inflation, being conceptually different from the cost of living, is not adequately captured by the standard price statistics. ${ }^{4}$ Thus it is argued that central banks ought to target a price index whose rate of increase corresponds to the inflation that generates the costs that central banks are seeking to avoid by focusing on an inflation-control objective. Inflation is costly to society because it disrupts the coordination of economic activity and discourages the use of fiat money in market transactions. Although it is possible that some of the costs of inflation are captured by changes in the cost of living, some of them may require a much broader measure of market transactions. One conclusion from this line of reasoning is that, for the purposes of monetary policy, what is needed is not a microeconomic theory of the cost of living, but a macroeconomic theory of the cost of inflation. Thus we can interpret various measures of core inflation as attempts to better measure this more-appropriate measure of inflation for monetary policy purposes.

\footnotetext{
4 See, for example, Howitt (1997).
}

But just how much guidance does the concept of monetary inflation provide when it comes to measurement? Consider a very standard money market equilibrium condition:

$$
\frac{M^{S}}{P}=L(Y, R),
$$

where $M^{S}$ denotes the stock of money, $P$ denotes the price level, $L(Y, R)$ denotes the demand for money, which is assumed to be a function of real income, $Y$, and the interest rate, $R$. What is the effect of a supply shock (e.g., a hike in oil prices or tax rates) on the price level? ${ }^{5}$ An adverse supply shock that lowers the level of output would, under standard assumptions about the nature of the demand for money, also lower the demand for real balances. Absent any action on the part of the central bank to alter the stock of money outstanding, $M^{S}$, the price level must rise to clear the market for real balances. Is this increase in the price level "monetary" inflation or not? It does not constitute monetary inflation in the sense that its proximate cause is something other than an action on the part of the central bank. It does constitute monetary inflation to the extent that, in principle, an appropriate response on the part of the central bank (cutting the stock of base money to match the decline in the demand for base money) could have prevented it from occurring. More generally, the inflation rate is determined by the rate of growth of the stock of money relative to the demand for it. The inflation rate is not uniquely determined by the monetary authorities, but by the monetary authorities and the private sector jointly.

\section{Origin, History, and Definition of Core Inflation}

Core inflation is a concept that has long lurked on the fringes of mainstream academic debate. Despite the frequency with which the term is used in policy discussions, it is rare that the term turns

5 Bryan and Cecchetti (1994, p. 195) argue that "during periods of poor weather, for example, food prices may rise to reflect decreased supply, thereby producing transitory increases in the aggregate index. Because these price changes do not constitute underlying monetary inflation, the monetary authorities should avoid basing their decisions on them." 
up in mainstream academic publications. This is perhaps surprising, given that the term has been around for quite some time. In a search of the JSTOR database, the first occurrence of the term "core inflation" is Schreder (1952). ${ }^{6}$ Schreder used the term in the context of a discussion of the inflationary gap that the United States was believed to be facing in the early 1950s and wrote that "even those who tend to agree with the concept of a rough balance between supply and demand, point out that there is still a huge money supply-and that is the hard core of inflation.... our money supply (currency outside banks and adjusted private demand deposits) is well over three times the 1939 level; and over the longer term basic economic factors, including prices, do tend to move into line with money supply" (Schreder, 1952, p. 153). Schreder does not provide any further discussion of core inflation, and the context in which he uses the term makes it hard to link his use with contemporary usage. The next reference turned up is Sprinkel (1975), who uses the term in the context of a discussion of the short-term outlook for the U.S. economy. Sprinkel (1975) writes that "profligate economic policies explain the average annual inflation of the past 3 years, but recent price increases of 10-12 percent annually were about double the hard-core inflation” (p. 1). Later in the same paper he refers to "the basic inflation of 5-6 percent..." (p. 4), suggesting that what he has in mind is some concept of trend inflation. Tobin (1981, p. 38) uses the term in the context of a discussion of sacrifice ratios: "Two or three point-years of extra unemployment bring down the inertial core inflation by only one point." Tobin does not provide any further discussion of core inflation, but what he seems to have in mind is some notion of trend expected inflation.

It would appear, then, that Eckstein (1981, p. v) was the first to propose a formal definition of core inflation, as the "trend rate of increase of the price of aggregate supply." Eckstein postu-

\footnotetext{
6 The JSTOR search was conducted over the 18 journals in the economics and finance categories. The search turned up 57 items matching the search constraints, which were set to be as broad as possible and included articles, reviews, opinion pieces, and other items.
}

lated that measured inflation, $\pi$, could be broken down into three components: core inflation, $\pi^{c}$; demand inflation, $\pi^{d}$; and shock inflation, $\pi^{s}$ :

$$
\pi=\pi^{c}+\pi^{d}+\pi^{s}
$$

Core inflation is measured as a weighted average of the rate of increase in unit labor costs and the user cost of capital and is essentially the rate of growth of the supply price of output along the steady-state growth path with a constantreturns-to-scale Cobb-Douglas production technology and Hicks-neutral technological change. That is, core inflation is defined as steady state inflation. Eckstein notes that "the core rate reflects those price increases made necessary by increases in the trend costs of the inputs to production.

The cost increases, in turn, are largely a function of underlying price expectations. These expectations are the results of previous experience, which, in turn, is created by the history of demand and shock inflation" (Eckstein, 1981, p. 8). Parkin (1984) in his review of Eckstein's book shows that Eckstein's definition of core inflation collapses to the steady-state growth rate of unit labor costs. ${ }^{7}$ Parkin's critique of Eckstein is noteworthy in a number of respects. If core inflation is nothing more than trend or expected inflation, it raises the question of why we would want to estimate trend or expected inflation indirectly rather than looking at direct measures of both.

The CPI Detailed Report for January 1978 was the first to routinely include the CPI All Items less Energy and All Items less Food and Energy measures. These indices were first reported in the CPI Detailed Report for December 1975 (in Table B, "Changes in Wholesale and Consumer Price Indexes 1973-75”). Thereafter, they were reported every three months in a special table until their regular inclusion in 1978. Note that the CPI Detailed Report and the publications it replaced regularly reported a variety of other special indices (such as "all items less food," "all items less shelter," "all items less medical care," from

\footnotetext{
7 By contrast, Blinder (1982) sees the growth rate of unit labor costs as a measure of core or underlying inflation that is distinct from Eckstein's) and is also equal to (the rationally expected or perfectly foreseen) expected inflation.
} 
a 1968 report). The March 2001 issue of Monthly Labor Review reports no fewer than 15 "special" indices that could be classified as measures of core inflation in the CPI tables (such as "all items less food and energy," "all items less shelter," "all items less medical care," etc.). In September 1981, the Monthly Labor Review carried an article by David Callahan (Callahan, 1981) explaining the differences between six alternative measures of core or underlying inflation. The earliest Fed publication on core or underlying inflation is Scadding (1979).

The Statistical Abstract of the United States for 1951 is the first that I can find to publish a chart of core WPI inflation (specifically, wholesale prices for all commodities other than farm products) (Figure XIV, p. 278). The 1953 edition of the Abstract provides monthly data on wholesale prices for all commodities other than farm products and foods from 1926 (Table 334, p. 303). The 1960 edition of the Abstract reports annual data for the CPI All Items excluding Food and All Items excluding Shelter back to 1935 (Table 438, p. 336). The original source cited for the data is Monthly Labor Review.

\section{ROLE OF THE CONCEPT OF CORE INFLATION IN MONETARY POLICY}

The Federal Reserve System is unusual among central banks in that it does not espouse a formal strategy for monetary policy. Unlike, say, the European Central Bank, the Federal Reserve System is not charged with the maintenance of price stability as its primary objective. Rather, the Federal Reserve Act states

The Board of Governors of the Federal Reserve System and the Federal Open Market Committee shall maintain long run growth of the monetary and credit aggregates commensurate with the economy's long run potential to increase production, so as to promote effectively the goals of maximum employment, stable prices, and moderate long-term interest rates. (Federal Reserve Act, 1-017)
As part of the Board's semiannual Monetary Policy Report, the Chairman of the FOMC reports on developments in the U.S. economy, including inflation, and also reports inflation outcomes and forecasts. The forecasts are those of the Governors and the Federal Reserve Bank presidents and had previously pertained to headline inflation-originally headline CPI inflation; then, from February 2000 through 2003, headline PCE inflation. ${ }^{8}$ Starting with the July 2004 Report, the FOMC has reported projections of core ("ex. food and energy”) PCE inflation. The analysis of recent developments also includes data for the core (excluding food and energy) CPI and PCE inflation rates. A number of authors have proposed that the United States adopt an inflation-targeting strategy for monetary policy similar to that pursued in a number of other countries. Bernanke et al. (1999) make such an argument and also suggest that the inflation target be defined in terms of some measure of core CPI inflation:
Although the particular choice of the price index used in constructing the inflation target is perhaps not critical, we lean towards the use of a "core" CPI measure that excludes food, energy and other volatile items from the price index. The core CPI is likely to provide a better guide to monetary policy than other indices, since it measures the more persistent underly- ing inflation rather than transitory influences on the price level. Moreover, its use indicates to the public that the central bank will respond flexibly to inflationary shocks arising from supply shocks (such as sharp increases in the prices of oil or food). Use of a core CPI measure also helps the central bank to communicate to the public that not every shock that raises prices will lead to a permanent increase in inflation, and that short-term changes in inflation result- ing from supply shocks will be treated differ- ently from changes driven by aggregate demand. (Bernanke et al., 1999, pp. 321-22)

\footnotetext{
8 In explaining the switch from the CPI to the PCE deflator, the FOMC noted that the PCE deflator was less susceptible to measurement error than the CPI because it uses an index formula that allows for commodity substitution in response to changes in relative prices, has more comprehensive coverage of expenditures than the CPI, and can be revised to take into account new information and improvements in measurement techniques. See Board of Governors of the Federal Reserve System (2000).
} 
The Federal Reserve System also stands out among central banks in that it has published relatively little research on the merits of competing measures of core inflation. The Federal Reserve Bank of Cleveland is an exception in this regard: The limited-influence estimators of core inflation proposed by Bryan and Pike (1991) and Bryan and Cecchetti (1994) have been widely emulated by other central banks. ${ }^{9}$

The Maastricht Treaty (or Treaty on European Union [EU]) stipulates that "the primary objective of the ESCB shall be to maintain price stability" (Maastricht Treaty Article 105). The ECB subsequently quantified price stability as "a yearon-year increase in the Harmonised Index of Consumer Prices (HICP) for the euro area of below 2\%” (ECB Press Release, October 13, 1998, “A stability-oriented monetary policy strategy for the ESCB”). Note that the ECB's communiqué on strategy contains no mention of core inflation. However, it does note that "the statement that 'price stability is to be maintained over the medium term' reflects the need for monetary policy to have a forward-looking, medium-term orientation. It also acknowledges the existence of short-term volatility in prices which cannot be controlled by monetary policy." Measures of core inflation are usually designed to eliminate some of this short-term volatility. However, the ECB does routinely report a variety of measures of core inflation in its Monthly Bulletin. In its first Bulletin, published in January 1999, it simply reported the rate of inflation for "non-energy industrial goods," which at that time accounted for about one third of the HICP. By December 2007, the ECB was routinely including additional core measures in its Monthly Bulletin, including traditional "ex. food and energy"-like measures.

The ECB has published a couple of working papers on core inflation-see Wynne (1999), Morana (2000), Vega and Wynne (2001), and Angelini, Henry, and Mestre (2001a,b)—but has

9 The only other studies of alternative measures of core inflation by Fed economists are Scadding (1979), McElhattan (1982), Motley (1997) (which is a commentary on Bryan and Cecchetti, 1994), and Cogley (1998). Clark (2001), Rich and Steindel (2005), and Khettry and Mester (2006) are more recent evaluations of core inflation measures for the United States. not formally endorsed one measure over another. It is worth noting that each month the European statistical agency Eurostat publishes five measures of core along with the headline HICP inflation rate for the EU and the euro area (specifically, HICP All-items excluding Energy; HICP All-items excluding Energy, Food, Alcohol, and Tobacco; HICP All-items excluding Tobacco; HICP All-items excluding Energy and Seasonal Food; and HICP All-items excluding Energy and Unprocessed Food).

The Bank of Japan has tended to emphasize a core-like measure of inflation in its communications with the general public. The minutes of the Bank's Monetary Policy Board routinely refer to the year-on-year increase in the CPI excluding fresh food in the assessment of domestic price developments. ${ }^{10}$ However, the Bank has made it clear that it interprets its mandate for price stability in terms of headline inflation: "In today's Monetary Policy Board Meeting... it was agreed that, by making use of the rate of year-on-year change in the consumer price index to describe the understanding of [price stability], an approximate range between zero and two percent was generally consistent with the distribution of each Board member's understanding of medium- to long-term price stability" (Bank of Japan, 2006).

Over the past decade and a half, inflation targeting has become increasingly popular as a framework for monetary policy. Inflation targeting as a strategy for monetary policy originated in New Zealand in 1990. The most recent Policy Targets Agreement (PTA) between the Reserve Bank of New Zealand (RBNZ) and the government adopted in May 2007 defines price stability as an annual rate of increase in the New Zealand all-groups CPI of between 1 and 3 percent over the medium term. However, the PTA also notes the following:

For a variety of reasons, the actual annual rate of CPI inflation will vary around the mediumterm trend of inflation, which is the focus of the policy target. Amongst these reasons, there is a

\footnotetext{
${ }^{10}$ Shiratsuka (2006) presents evidence that the CPI excluding fresh food and the 10 percent trimmed mean do a better job at tracking trend inflation and forecasting future headline inflation in Japan than other measures of core inflation.
} 
range of events whose impact would normally be temporary. Such events include, for example, shifts in the aggregate price level as a result of exceptional movements in the prices of commodities traded in world markets, changes in indirect taxes, significant government policy changes that directly affect prices, or a natural disaster affecting a major part of the economy... When disturbances of the kind described [above] arise, the Bank will respond consistent with meeting its medium-term target.

The first PTA (in 1990) specified a target range for inflation of 0 to 2 percent. The agreement noted that "the primary measure of prices used to calculate the inflation rate for the purpose of these targets should relate to the prices of goods and services currently consumed by households. Unfortunately, the All Groups Consumers Price Index (CPI) is not an entirely suitable measure of these prices since it also incorporates prices and servicing costs of investment-related expenditures, notably in the housing field" and directed that "the Bank is to prepare an alternative measure of consumer prices based on an internationally comparable approach, so as to provide a basis for assessing the impact of investment-related housing costs on the CPI" (Reserve Bank of New Zealand, 1990). Subsequent PTAs stated explicitly that the price stability target was defined in terms of the all-groups CPI, but continued to note that a variety of shocks could cause short-term deviations of the CPI from the target range. Invoking these clauses in the PTA, the RBNZ targeted a measure of underlying inflation it constructed itself by excluding credit services from the CPI (CPIX). In 1997, the target was redefined in terms of the CPIX published by Statistics New Zealand (RBNZ, 1997a,b) and the Bank discontinued its own series on underlying inflation. And as already noted in 1999, the target was once again specified in terms of the all-groups CPI after the introduction of a revised CPI in September 1999 that no longer included interest costs (which were usually the main source of differences between the headline inflation rate and the RBNZ's estimate of underlying inflation; see RBNZ, 1999). However, the 1999 PTA explicitly states that "the underlying trend in prices...is the proper focus of monetary policy." The RBNZ routinely publishes on its website statistics for CPI inflation and a number of core measures: CPI excluding Credit Services (CPIX) and Weighted Median CPI. The RBNZ has also published a number of working papers examining the properties of alternative measures of core inflation. See Roger (1995, 1997, and 1998) and, more recently, Giannone and Matheson (2006).

The Bank of Canada adopted inflation targeting in 1991. The target is defined in terms of the 12-month rate of change in the headline CPI. Under the most recent agreement between the government of Canada and the Bank of Canada (dated November 23, 2006), the target for inflation is set at 2 percent, with a "target range" of 1 to 3 percent, unchanged from the agreement reached in 2001. Note that, although the target is specified in terms of headline inflation, core inflation plays a key role in monetary policy deliberations. In documentation released in conjunction with the latest renewal of the inflation target, the Bank of Canada (2006, p. 7) noted that "measures of core inflation, along with indicators of capacity pressures, have been shown to be useful indicators of underlying inflation and, hence, or where total CPI inflation could be in the future. For this reason, core inflation provides a useful guide for the conduct of monetary policy." The latest headline and core CPI (CPIX) inflation statistics are prominently displayed on the first page of the Bank of Canada's website. The CPIX measure of core inflation excludes the eight most volatile components (fruits, vegetables, gasoline, fuel oil, natural gas, mortgage interest, inter-city transportation, and tobacco products) of the Canadian CPI. The CPIX measure also excludes the effects of changes in indirect taxes on the remaining components of the CPI. The Bank of Canada also tracks a different measure of core, the CPIW, which re-weights the components of the CPI using weights that are inversely proportional to the volatility of the component series. ${ }^{11}$ Both measures of core inflation are also regularly featured in the Bank of Canada's Monetary Policy Report. The Bank of

\footnotetext{
${ }^{11}$ The construction of the CPIW series is explained in more detail in Hogan, Johnson, and Laflèche (2001) and Laflèche (1997). Bank of Canada (1991) explains the construction of the CPI net of tax effects.
} 
Canada (2006) further clarified the use of its measure of core inflation in its deliberations: "It should be noted, however, that core inflation provides a useful guide to the extent that total CPI inflation is expected to converge to core inflation. If this were not expected to be the case, owing to anticipated persistent changes in the CPI components that are excluded from the core measure, total CPI inflation would take precedence" (Bank of Canada, 2006, p. 7, emphasis added).

The Bank of England has pursued inflation targeting since October 1992 and has published a quarterly Inflation Report since February 1993. The inflation target is set by the government and was originally defined in terms of a corelike measure of inflation, the retail price index excluding mortgage interest payments, or RPIX. The RPIX includes food and energy prices traditionally excluded from a measure of core. The Bank of England also routinely monitored a measure of retail price inflation that excludes, in addition to mortgage interest costs, the first-round effects of indirect taxes (i.e., the RPIY) and a measure of domestically generated inflation (i.e., the RPIX excluding import prices). Both were reported on a regular basis in the Bank of England's quarterly Inflation Report, along with a number of alternative measures of core inflation, including the median and the (15 percent) trimmed mean, and measures of domestically generated inflation (arguably interpretable as core inflation). Examples of the last of these include the HARP (Housing-Adjusted Retail Prices, an adjusted version of RPIX that replaces the Central Statistics Office/Office of National Statistics estimate of housing depreciation with an estimate of the user cost of housing calculated by the Bank of England), THARP (a similarly adjusted version of RPIY, introduced in the November 1994 Inflation Report), RPIX excluding export prices, unit labor costs, and unit labor costs based on trend productivity. ${ }^{12}$ The trimmed mean and weighted median measures of Bryan and Cecchetti were first reported by the Bank of England in its May 1993

${ }^{12}$ Bank of England's first Inflation Report (February 1993) included a short discussion of the treatment of owner-occupied housing in the RPI and the construction of the HARP index.
Inflation Report, while the Quah-Vahey measure (which was referred to as "output-neutral" inflation) was introduced in the August 1993 Inflation Report. ${ }^{13}$ The Bank also occasionally publishes analyses of how various fiscal measures affect RPIX inflation. For example, in the May 2001 Inflation Report it reported estimates of the effects of increases in various taxes and duties prepared by the U.K. Office of National Statistics. ${ }^{14}$ The Bank of England has also published a number of research papers explaining the construction and examining the properties of alternative measures of core inflation: Cutler (2001), Bakhshi and Yates (1999), Beaton and Fisher (1995), and Quah and Vahey (1995). ${ }^{15}$

However, in recent years, the Bank of England seems to have greatly downplayed the importance of core inflation in its deliberations or communications with the general public. Indeed, there has been no mention of the concept of core inflation in any of the Bank's Inflation Reports since November 2000. Bean (2006) makes the following observation: "The fact that the rise in oil prices is the flip side of the globalization shock to me renders highly suspect the practice of focussing on measures of core inflation that strip out energy prices while retaining the falling goods prices." The Bank's inflation target, which was originally defined in terms of the core-like RPIX, was redefined in terms of the headline CPI or HICP in 2003.

Sveriges Riksbank (the Bank of Sweden) adopted inflation targeting in 1993. The Bank of Sweden's inflation target is defined in terms of the headline rate of increase in the CPI (since 1995, 2 percent \pm 1 percent). The Bank of Sweden routinely reports two measures of core inflation in

\footnotetext{
${ }^{13}$ Interestingly enough, that seems to have been the one and only appearance of the Quah-Vahey measure in the Bank of England's Inflation Report. In a speech published in the subsequent (November 1993) issue of the Bank of England Quarterly Bulletin, the Deputy Governor noted that "all the senior people in the Bank believe that inflation's roots lie in excessive monetary expansion. We all believe that inflation is deeply damaging to the real economy of jobs and output and spending and growth."

${ }^{14}$ See Bank of England (2001, p. 42).

${ }^{15}$ Bank of England's first Inflation Report (February 1993) included a footnote mentioning the possibility of defining core inflation in terms of the component of observed inflation that is uncorrelated with output in the long run.
} 
its regular Inflation Report (since 2007 renamed Monetary Policy Report): UND1X, which is defined as the CPI excluding interest expenditure and direct effects of altered indirect taxes and subsidies; and UNDINHX, which is the CPI excluding interest expenditure, goods that are mainly imported, and direct effects of altered domestic indirect taxes and subsidies. Since 1999 the Riksbank has also reported a model-based measure of core inflation based on the research of Apel and Jansson (1999), which is explained at some length in Inflation Report (1999, pp. 51-52). Other research published by the Bank of Sweden on core inflation and its role in monetary policy includes Nessén and Söderström (2000) and Blix (1995). In their review of Swedish monetary policy over the period 1995-2005, Giavazzi and Mishkin (2007) recommended that the Bank's inflation target should be defined in terms of a price index that is not directly affected by the costs of owneroccupied housing, such as the UND1X measure, but this recommendation was rejected by the Executive Board.

The Reserve Bank of Australia also adopted inflation targeting as its strategy for monetary policy in 1993. The inflation target was originally specified in terms of the underlying rate of CPI inflation and as expressed as a range of 2 to 3 percent per annum. The most recent Statement on the Conduct of Monetary Policy issued in December 2007 stated that
In pursuing the goal of medium-term price stability, both the Reserve Bank and the Government agree on the objective of keeping consumer price inflation between 2 and 3 per- cent, on average, over the cycle. This formula- tion allows for the natural short run variation in underlying inflation over the cycle while preserving a clearly identifiable benchmark performance over time. (Reserve Bank of Australia, 2007)

Note that the wording of this statement is somewhat different from that in the 1996 statement (Reserve Bank of Australia, 1996), which referred to the objective of keeping underlying inflation

in the 2 to 3 percent range over the cycle, without specifying which measure of underlying inflation was to be used. In late 1998 the Reserve Bank of Australia announced that in the future the inflation target would be interpreted as referring to the headline CPI inflation rate rather than any measure of core (see Reserve Bank of Australia, 1998), and the switch from underlying to overall consumer price inflation was made in the 2003 statement. The reason for the change was improvements (changes) in the treatment of housing in the CPI as part of the regular periodic (five-year) review of the Australian CPI, specifically the switch from the use of mortgage interest costs to measure changes in the costs of owner-occupied housing to the treatment of owner-occupied housing on a net acquisitions basis. The Bank regularly publishes a number of measures of core inflation in its quarterly Statement on Monetary Policy, including the trimmed mean, the weighted median, the CPI excluding volatile items (which is the CPI excluding fruit and vegetables and automotive fuel), and market goods and services excluding volatile items. This last item excludesin addition to the items already excluded from the CPI excluding volatile items-utilities, property rates and charges, health, other motoring charges, urban transport fares, postal, education, and child care categories. (See for example Table 11 in the May 2001 Statement. ${ }^{16}$ ) The Reserve Bank of Australia has also published in its Bulletin a number of articles explaining the computation of underlying inflation (Reserve Bank of Australia, 1994) and a number of research papers on alternative measures of core: Kearns (1998), Roberts (2005), and Brischetto and Richards (2006).

This brief review of current practice shows that central banks tend to differ in the importance they assign to the concept of core inflation. Insofar as a measure of core inflation plays a role in monetary policy, whether as a target or as a means of communicating with the general public, central banks invariably rely on traditional exclusiontype measures of core. A number of central banks also report some of the newer measures of core, especially variants of the limited influence measures advocated by Bryan and Cecchetti.

\footnotetext{
${ }^{16}$ See Australian Bureau of Statistics (2000).
} 


\section{THE BASIC FRAMEWORK}

The stochastic approach to index numbers has (implicitly or explicitly) formed the basis of many recent attempts to improve upon existing core inflation measures. In the academic literature, this approach is exemplified by the papers by Clements and Izan $(1981,1987)$ as well as a book by Selvanathan and Prasada Rao (1994). The research of Bryan and Pike (1991), Bryan and Cecchetti $(1993,1994)$, and Cecchetti (1997) has brought this approach to inflation measurement to the attention of monetary policymakers in the United States, while the work of Quah and Vahey (1995), Blix (1995), and Fase and Folkertsma (1996) indicates that this alternative way of thinking about inflation is also influential among the national central banks in the EU. Diewert (1995) provides a critique of this literature from the perspective of the traditional economic approach to price measurement; some additional discussion is to be found in Wynne (1997).

The point of departure for all attempts to measure core inflation is the observation that the changes in the prices of individual goods and services between two periods contain a common component that constitutes core inflation and an idiosyncratic component that primarily reflects developments in local markets. The problem of core inflation measurement is then to isolate these two components of observed price changes. This idea is formalized by writing

$$
\pi_{i, t}=\Pi_{t}+x_{i, t} .
$$

This expression defines the rate of change of the price of an individual commodity, $\pi_{i, t}=\ln \left(p_{i, t}\right)-$ $\ln \left(p_{i, t-1}\right)$, as consisting of an aggregate inflation component, $\Pi_{t} \equiv \ln \left(P_{t}\right)-\ln \left(P_{t-1}\right)$, and a relative price change component, $x_{i, t}$. The object we are interested in is $P_{t}$, the common component of all prices and what we might interpret as the purchasing power of money. Different approaches to the measurement of core inflation can be characterized by how they go about achieving identification.

The presumption in all of these approaches is that the "headline" rate, which is some weighted average of the individual price changes,

$$
\sum_{i=1}^{N} w_{i, t} \pi_{i, t},
$$

with weights chosen on the basis of expenditure shares, is a poor or second-best approximation to $\Pi_{t}$. What differentiates the various approaches to core inflation measurement is the information that is used to arrive at the core measure. One approach is to simply recombine the price changes of individual goods and services at each point in time to derive a core measure. This is the "ex. food \& energy" approach and also the essence of the limited influence measures (such as the trimmed mean and weighted median) advocated by Bryan and Cecchetti. Alternatively, we might choose to ignore the information in the cross-section distribution of individual price changes and instead derive a measure of core inflation by smoothing current and previous headline inflation rates. Thus some have advocated constructing a measure of core inflation by taking a moving average of past inflation rates or applying a Hodrick-Prescott (1997) filter to headline rates. Between these two extremes is the dynamic factor index proposed by Bryan and Cecchetti (1993), which combines information on both the time-series and crosssection characteristics of individual price changes.

\section{ESTIMATING CORE INFLATION USING ONLY CONTEMPORANEOUS PRICE DATA}

There is some intuitive appeal to the idea that we can somehow isolate the monetary component of price changes by simply averaging the changes in the prices of individual goods and services. This approach to inflation measurement has a long history and was perhaps first fully articulated by Jevons (1865). Jevons argued for the use of the geometric mean of price changes in calculating inflation

as it seems likely to give in the most accurate manner such general change in prices as is due to a change on the part of gold. For any change in gold will affect all prices in an equal ratio; and if other disturbing causes may be considered proportional to the ratio of change of price 
they produce in one or more commodities, then all the individual variations of prices will be correctly balanced off against each other in the geometric mean, and the true variation of the value of gold will be detected. (Jevons, 1865, p. 296)

If we interpret the relative price term, $x_{i, t}$, in the equation above as an error term that is normally distributed, with mean and variance given by $E\left(x_{t}\right)=0, E\left(x_{t} x_{t}{ }^{\prime}\right)=\sigma_{t}^{2} I_{N}$, where $x_{t}=\left[x_{1, t}, x_{2, t}\right.$, $\left.\ldots x_{N, t}\right]^{\prime}$, it is straightforward to show that the maximum likelihood estimator of the inflation rate, $\hat{\Pi}_{t}$, is given by a simple unweighted average of the rates of change of the individual price series ${ }^{17}$ :

$$
\hat{\Pi}_{t}=\frac{1}{N} \sum_{i=1}^{N} \pi_{i, t} .
$$

Note that we identify core inflation in this model by defining it as the component of price changes that is orthogonal to relative price changes. By construction, the estimated relative price changes, $\hat{x}_{i, t}$, have the property

$$
\sum_{i=1}^{N} \hat{x}_{i, t}=0
$$

That is, the implied relative price changes average to zero.

Taking the exponential of both sides of the proposed measure of inflation, we obtain the geometric mean price index proposed by Jevons (1865) as a way of computing the change in the purchasing power of money over time:

$$
\exp \left(\hat{\Pi}_{t}\right)=\prod_{i=1}^{N}\left(\frac{P_{i, t}}{P_{i, t-1}}\right)^{1 / N} .
$$

This measure of inflation has a number of appealing properties, not the least of which is the ease with which it can be calculated. Unlike a simple arithmetic mean of price relatives $\left(p_{i, t} / p_{i, t-1}\right)$ (the so-called Carli index), this index satisfies the time reversal property. ${ }^{18}$ Fase and Folkertsma (1996) argue for the use of simple

\footnotetext{
${ }^{17}$ See Diewert (1995).

${ }^{18}$ A price index is said to satisfy the time reversal property if, when we reverse the order of time, the recalculated index is simply the reciprocal of the previously calculated index.
}

averages of price changes to isolate core inflation in a structural vector autoregression (VAR) framework (discussed below). However, this measure of inflation also has a number of serious shortcomings, all of which ultimately relate to the strong assumptions made about the behavior of the relative price terms, $x_{i, t}$.

Note that so far nothing has been said about which prices to include in the calculations. The prices that are averaged to arrive at a measure of inflation could be just consumer prices, or could include the prices of all gross domestic product (GDP) transactions or the prices of all transactions (including intermediate transactions), or could even include the prices of assets. Fisher (1920) argued that when it comes to constructing a measure of the purchasing power of money, we ought to look at as many prices as possible:
Perhaps the best and most practical scheme [for the construction of an index number] is that which has been used in the explanation of [the price level] $P$ in our equation of exchange, an index number in which every article and service is weighted according to the value of it exchanged at base prices in the year whose level of prices it is desired to find. By this means, goods bought for immediate consumption are included in the weighting, as are also all durable capital goods exchanged during the period covered by the index number. What is repaid in contracts so measured is the same general purchasing power. This includes purchasing power over everything purchased and purchasable, including real estate, securi- ties, labor, other services, such as the services rendered by corporations, and commodities. (Fisher, 1920, pp. 217-18)

It is interesting to note that the preamble to the European Council Regulation governing the calculation of the HICP, which will form the basis for assessing inflation developments in the euro area, notes that "it is recognised that inflation is a phenomenon manifesting itself in all forms of market transactions including capital purchases, government purchases, payments to labour as well as purchases by consumers" (European Commission, 1998). Once we have abandoned the cost of living as the guiding concept for inflation measurement 
for monetary policy purposes, there is no reason for confining our attention to changes in the prices of final consumer goods. Changes in the prices received by producers, changes in the prices of intermediate goods, and changes in the prices of existing assets all carry information about monetary inflation.

\section{ARE ALL PRICES EQUALLY INFORMATIVE?}

One possible problem with this approach to estimating inflation is that it treats all prices as being equally informative about inflation and thus equally important. ${ }^{19}$ Arguably a more appropriate approach would be to weight the price changes of individual products in terms of their importance, somehow defined. ${ }^{20}$ That is, an estimate of inflation of the form

$$
\hat{\Pi}_{t}=\sum_{i=1}^{N} w_{i, t} \pi_{i, t}
$$

(which assigns weights $w_{i, t}$ to the price changes of individual products in arriving at a measure of overall inflation) may be preferable. Diewert (1995) shows that, for this expression to be the maximum likelihood estimator of the inflation rate, we can retain our original assumption that the relative price changes have zero mean, but need to replace the variance assumption with

$$
E\left(x_{t} x_{t}^{\prime}\right)=\sigma_{t}^{2} W_{t}^{-1}
$$

\footnotetext{
${ }^{19}$ Diewert (1997) sees this property of the Jevons index number as a "fatal flaw."

${ }^{20}$ The contrary view is taken by Bryan and Pike (1991), who write "the strength of the inflation signal in goods and services prices is not necessarily related to an item's share of the typical household budget. As a monetary phenomenon, inflation should influence the price of all goods and services equally. The inflationary signal in the price of a new pair of shoes is theoretically the same as that in the price of shoe leather or, for that matter, in the price of cows. There is no reason to expect movements in the price of one to be a clearer indicator of inflation than movements in the prices of others." Likewise Fase and Folkertsma (1996) note "weighting the price index means that some prices get to determine the general price level thus measured more than others. For an assessment of changes in purchasing power, weighting may certainly be useful but there is no clear reason to gauge inflation by way of weighting."
}

where $W_{t}=\operatorname{diag}\left[w_{1, t}, w_{2, t}, \ldots w_{N, t}\right]$. This assumption about the distribution of relative price changes was proposed by Clements and Izan (1981). They argued as follows: "If we think in terms of sampling of the individual prices to form ... $\left[\pi_{i, t}\right] \ldots$ for each commodity group, then it seems reasonable to postulate that the collection agency invests more resources in sampling the prices of those goods more important in the budget. This implies that ... $\left[\operatorname{Var}\left(x_{i, t}\right)\right] \ldots$ is inversely proportional to ...[ $\left.w_{i, t}\right]$ " (Clements and Izan, 1981, p. 745). Later Clements and Izan (1987) provided a different justification for this assumption, arguing that the larger an item looms in the budget of consumers, the less scope there is for relative price changes in that item. Neither of these justifications is particularly appealing. However, the theory of the cost-of-living index provides an alternative rationale for weighting individual price changes by shares in consumer's budgets. A fixed-weight Laspeyres measure of the price level at date $t$ with period 0 as the base period can be written as

$$
P_{t}^{L}=\frac{\sum_{i=1}^{N} p_{i, t} q_{i, 0}}{\sum_{i=1}^{N} p_{i, 0} q_{i, 0}}=\sum_{i=1}^{N} w_{i, 0}\left(\frac{p_{i, t}}{p_{i, 0}}\right)=\sum_{i=1}^{N} w_{i, 0} p_{i, t},
$$

where we set $p_{i, 0}=1, \forall i$. By log-differentiating this expression, we obtain

$$
\frac{d P_{t}}{P_{t-1}} \equiv \Pi_{t}=\frac{1}{P_{t-1}} \sum_{i=1}^{N} w_{i, 0} d p_{i, t}=\sum_{i=1}^{N} r_{i, t} \pi_{i, t}
$$

That is, the standard fixed-weight Laspeyres measure of inflation can be written as a weighted average of the rates of change of the prices of individual goods and services. However, note that the weights, $r_{i, t}$, are not the budget share weights of the base period, $w_{i, 0}$. Rather, they are the "relative importances" of each product-that is, the base-period weight adjusted for the extent to which the price of the good in question has grown faster or slower than prices on average. Goods whose prices increase faster than average over time will have an increasing relative importance in a fixed-weight Laspeyres type price index. This is simply another way of expressing the well- 
known tendency of fixed-weight Laspeyres measures to overstate the true rate of inflation as defined by the cost-of-living index. ${ }^{21}$

But why do we need to confine ourselves to looking to budget shares for weights? The use of budget shares as weights is best motivated by an appeal to the (a temporal) theory of the cost-ofliving index. Yet, implicit in the notion of core inflation that ought to be of primary concern to monetary policymakers is the idea that such inflation is inherently different from inflation as measured by the cost-of-living index. Thus, the weighting scheme that is optimal for constructing a cost-of-living index may no longer be optimal for measuring inflation for the purposes of monetary policy.

A weighting scheme that might be more appropriate for monetary policy purposes would weight prices by the strength or quality of the inflation "signal" they provide. Indeed, this is the approach that implicitly underlies the "ex. food \& energy" or "ex. indirect taxes" approaches to estimating core inflation that are used by many central banks and statistical agencies. In these approaches we attach zero weight to certain prices on the (unstated) grounds that they convey zero information about core inflation. Formally,

$$
w_{i}=0 \text { if } \sigma_{i}^{2}>\tilde{\sigma}^{2},
$$

where $\tilde{\sigma}^{2}$ is some "unacceptably high" level of variability in short-term price changes. It is worth noting that there is no justification for such a practice within the theory of the cost-of-living index; the rationale for excluding certain prices from an estimate of core inflation must lie elsewhere.

One scheme for weighting prices in terms of the quality of their inflation signal would be to set the weights as follows:

$$
w_{i}=\frac{\frac{1}{\sigma_{i}^{2}}}{\sum_{i=1}^{N} \frac{1}{\sigma_{i}^{2}}} .
$$

That is, choose weights for the various individual prices that are inversely proportional to the volatility of those prices. A weighting scheme along

\footnotetext{
${ }^{21}$ For further details, see Blinder (1980).
}

these lines has been investigated by Dow (1994), who termed the resulting measure of inflation a variance-weighted price index, and by Diewert (1995), who termed the resulting measure of inflation neo-Edgeworthian. Wynne (1997) reports the results of applying a scheme along these lines to U.S. CPI data. The advantage of employing a variance weighting scheme to calculate core inflation is that we do not discard potentially useful information about core inflation that may be contained in food and energy prices-or whatever categories are excluded. The "ex. food \& energy" approach to estimating core inflation is further compromised by the need for a once-and-for-all judgment about what the least informative categories of prices are for estimating core inflation. A variance weighting scheme such as that noted above allows weights to change over time as the volatility of different categories of prices changes over time. The speed with which the weights will change in response to changes in volatility will be determined by the choice of the estimation "window" for the variances.

Yet another weighting scheme was proposed informally by Blinder (1997). Starting from a definition of core inflation as the persistent or durable component of inflation, Blinder suggests that when it comes to calculating core inflation, individual price changes should be weighted by their ability to forecast future inflation. Blinder argues that central bankers are a lot more concerned about future inflation than they are about past inflation; and, when we think about the measurement of core inflation as a signal extraction problem, future inflation is the object about which we are seeking information through current signals. Thus core inflation is defined in terms of its ability to predict future headline inflation. Smith (2007) is an attempt to implement this approach. ${ }^{22}$

\section{SOME PROBLEMS}

If we think about the problem of core inflation measurement in terms of an estimation problem,

\footnotetext{
${ }^{22}$ However, note that Bryan and Cecchetti (1994) evaluate various measures of core inflation in terms of their ability to forecast future inflation.
} 
we need to ask whether the distribution assumptions that underlie the estimation are borne out by the data. There are three important distributional assumptions that need to be looked at. The first is that individual price changes are normally distributed; the second is that individual price changes are independent of one another; and the third is that price changes are identically distributed.

The geometric mean of price relatives is the maximum likelihood estimator of core inflation under the assumption that individual price changes are normally distributed. But this assumption is not borne out by the data.

There is an extensive literature documenting the statistical properties of individual price changes, and it is clear that individual $\pi_{i, t}$ are typically not normally distributed. This fact was first noted by Bowley (1928) in a critique of Jevons and has subsequently been further documented by Vining and Elwertowski (1976), Ball and Mankiw (1995), Cassino (1995), Bryan and Cecchetti (1996), and Balke and Wynne (2000). There is evidence of significant skewness and kurtosis in the crosssection distribution of price changes. Skewness in the distribution of price changes may reflect the fact that changes in the money stock do not necessarily affect all prices at the same time, ${ }^{23}$ or it may simply reflect skewness in the underlying shocks that causes relative prices to change. ${ }^{24}$

If the distribution of $\pi_{i, t}$ can be characterized in terms of a distribution with a finite number of moments, it may still be possible to estimate core inflation as the solution to a maximum likelihood problem. However, the resulting measure will probably be significantly more complicated than a simple geometric mean of price relatives.

A more constructive response to non-normality in the distribution of $\pi_{i, t}$ is to employ estimators that are robust to departures from normality. This is the approach advocated by Bryan and Pike

\footnotetext{
${ }^{23}$ Indeed, Ball and Mankiw (1995) argue that this property of the distribution of price changes is important evidence favoring stickyprice or menu-cost models of real-nominal interactions.

${ }^{24}$ Balke and Wynne (2000) propose this interpretation.
}

(1991), Bryan and Cecchetti (1994, 1996), and Cecchetti (1997). Bryan and Pike argue for the use of the median of $\pi_{i, t}$ as an estimate of core inflation on the grounds that the median is a more robust measure of central tendency. Bryan and Cecchetti (1994) examine in more detail alternative approaches to estimating core inflation and conclude that, of the various measures they look at, the weighted median CPI performs best. More recently Bryan, Cecchetti, and Wiggins (1997) investigate the ability of various trimmed means of the cross-section distribution of price changes to track trend inflation. To compute the trimmed mean of the cross-section distribution of prices, start by ordering the sample (from largest to smallest price change, say). Then define the cumulative weight from 1 to $i$ as

$$
w_{i, t}=\sum_{j=1}^{i} w_{(j), t},
$$

where $w_{(j), t}$ denotes the sorted $j$ th weight. This allows us to define the index set

$$
I_{\alpha}=\left\{i: \alpha<W_{i, t}<1-\alpha\right\} .
$$

The $\alpha$-percent trimmed mean inflation rate is then defined as

$$
\bar{\Pi}_{t}^{k}(\alpha)=\frac{1}{1-2 \alpha} \sum_{i \in I_{\alpha}} w_{(i), t} \pi_{(i), t}^{k},
$$

where $\pi_{(j), t}$ is the sorted $j$ th price change. If $\alpha=0$, we obtain the weighted sample mean. For $\alpha=0.50$, we define $\bar{\Pi}_{t}^{k}(\alpha)$ as the weighted sample median.

A further objection to the use of the geometric mean is that changes in relative prices are not independent of each other. Thus if we continue to think about core inflation measurement as an estimation problem, the assumption that $E\left(x_{t} X_{t}^{\prime}\right)=$ $\sigma_{t}^{2} I_{N}$ needs to be replaced with the more realistic assumption $E\left(x_{t} x_{t}^{\prime}\right)=\sigma_{t}^{2} \Omega$. In this case the core inflation rate can in principle be estimated as

$$
\hat{\Pi}_{t}=\left(\imath_{N}^{\prime} \Omega^{-1} \imath_{N}\right)^{-1} \imath_{N}^{\prime} \Omega^{-1} \pi_{t},
$$

where $t_{N}$ is an $N \times 1$ vector of 1 's. In practice, however, putting this approach into practice would require making strong assumptions about the 
precise nature of the interaction between relative prices (i.e., specification of $\Omega$ ); to date there do not appear to have been any attempts to construct estimates of core inflation along these lines.

A more fundamental objection to the use of the geometric mean is that it requires the systematic component of each price change to be the same, thereby precluding any long-term changes in relative prices. Casual empiricism suggests that this restriction is seriously at odds with reality. This criticism of the geometric mean of individual price changes as an estimate of inflation was first made by Keynes (1930).

Clements and Izan (1987) proposed a way around this problem. They start by writing

$$
\pi_{i, t}=\Pi_{t}+x_{i, t}=\Pi_{t}+r_{i}+\varepsilon_{i, t},
$$

where the relative price term, $x_{i, t}$, now contains a non-zero component, $r_{i}$, as well as a mean-zero stochastic component, $\varepsilon_{i, t}$. Assume

$$
E\left(\varepsilon_{t}\right)=0, E\left(\varepsilon_{t} \varepsilon_{t}^{\prime}\right)=\sigma_{t}^{2} W_{t}^{-1},
$$

where $W_{t}=\operatorname{diag}\left[w_{1, t}, w_{2, t}, \ldots w_{N, t}\right]$. To identify $\Pi_{t}$ and $r_{i}$, add the identifying assumption

$$
\sum_{i=1}^{N} w_{i, t} r_{i}=0 .
$$

The maximum likelihood estimator of the inflation rate is the same as in the basic model (i.e., a simple weighted average of the individual price changes), but now the expected change in the $i$ th relative price is $E\left(\pi_{i, t}-\Pi_{t}\right)=r_{i}$. Although this model is an advance over the simple framework, it is not obvious that the assumption of constant (time invariant) rates of relative price changes is any more palatable than the assumption of no systematic changes in relative prices. For many products, their relative prices tend to follow a U-shaped pattern over their lifetimes: rapid relative price declines following the introduction of a product, relative price stability as the product reaches maturity, and relative price increases as the product is displaced by newer products before finally disappearing from the market.
COMBINING CONTEMPORANEOUS AND TIME-SERIES INFORMATION TO ESTIMATE CORE INFLATION

Perhaps a more serious shortcoming of these models is that they fail to take account of persistence in both individual price changes and the inflation rate. Some of the dynamic models that have been proposed in recent years seek to remedy this problem- and succeed to varying degrees. We will start by looking at the dynamic factor index (DFI) model proposed by Bryan and Cecchetti (1993) and Cecchetti (1997). This model is of interest for many reasons, not least of which is the fact that it is the only model that attempts to combine information on both the cross-section and time-series characteristics of individual price changes in deriving a core inflation measure.

The DFI model starts with the equation

$$
\pi_{t}=\Pi_{t}+x_{t},
$$

where, as before, $\pi_{t}=\left[\pi_{1, t}, \pi_{2, t}, \ldots, \pi_{N, t}\right]^{\prime}$ and $x_{t}=$ $\left[x_{1, t}, x_{2, t}, \ldots, x_{N, t}\right]^{\prime}$. Identification of the common inflation component in all price changes (core inflation) is accomplished by positing time-series processes for inflation and the relative price change components of individual price changes as follows:

$$
\begin{aligned}
& \Psi(L) \Pi_{t}=\delta+\xi_{t} \\
& \Theta(L) x_{t}=\eta_{t},
\end{aligned}
$$

where $\Psi(L)$ and $\Theta(L)$ are matrix polynomials in the lag operator $L$ and $\xi_{t}$ and $\eta_{t}$ are scalar and vector i.i.d. processes, respectively. If $\Psi(L)=1$ and $\Theta(L)=1$, we obtain the static model discussed at length above. Another special case of this model where $\Psi(L)=1-\psi_{1} L$ and $\Theta(L)=1$ has been studied by Dow (1994). Bryan and Cecchetti (1993) and Cecchetti (1997) estimate versions of this model assuming that $\Psi(L)=1-\psi_{1} L-\psi_{2} L^{2}$ and $\Theta(L)=1-$ $\theta_{1} L-\theta_{2} L^{2}$.

In the DFI model the common element in all price changes, $\Pi_{t}$, is identified by assuming that it is uncorrelated with the relative price disturbances at all leads and lags instead of just contemporaneously. This is clearly a much stronger identifying assumption than is used in the simple 
static factor models discussed above (where inflation is defined as the component of price changes that is uncorrelated with relative price changes contemporaneously). It is not clear what is obtained by employing this stronger assumption. The DFI model is also susceptible to the criticism that it allows for only constant trends in relative prices. But perhaps the biggest shortcoming of the DFI approach to measuring core inflation is that history changes each time a new observation is obtained and the model is reestimated. This problem is common to all measures of core inflation constructed using econometric procedures. While this is not usually ranked as a major concern in choosing and constructing a measure of core inflation, it is of great importance to a central bank that plans to use a core measure as an integral part of its communications with the general public about monetary policy decisions.

A recent paper by Reis and Watson (2007) uses a similar approach to identify what they call "pure inflation." They start with linear factor model

$$
\pi_{t}=\Lambda F_{t}+x_{t},
$$

where, as before, $\pi_{t}=\left[\pi_{1, t}, \pi_{2, t}, \ldots, \pi_{N, t}\right]^{\prime}$ and $x_{t}=$ $\left[x_{1, t}, x_{2, t}, \ldots x_{N, t}\right]^{\prime}$. The vector $F_{t}$ has $k$ elements or factors that capture the common sources of variation in individual prices, while the vector $x_{t}$ captures the relative price variation in the prices of individual goods that is due to idiosyncratic sectoral events or measurement error. The aggregate component of price changes is further decomposed into an absolute-price component, denoted by the scalar $a_{t}$, and several relative price components, denoted by the $k-1$ element vector $R_{t}$ :

$$
\Lambda F_{t}=l_{N} a_{t}+\Gamma R_{t}
$$

where $t_{N}$ is an $N \times 1$ vector of 1 's and $\Gamma$ is an $N \times$ $(k-1)$ matrix. Reis and Watson identity "pure inflation" as

$$
\Pi_{t}=a_{t}-E\left\{a_{t} \mid\left\{R_{\tau}\right\}_{\tau=1}^{T}\right\} .
$$

That is, they define it as the common component in price changes that has an equiproportional effect on all prices and is uncorrelated with changes in relative prices at all dates. The "pure inflation" series thus identified (using quarterly data on the components of the personal consumption expenditures deflator) accounts for up to one-fifth of the overall variation in inflation in the United States.

\section{DYNAMIC MODELS II: BRINGING SOME MONETARY THEORY TO BEAR ON THE DEFINITION OF CORE INFLATION}

Core inflation as identified by the static and dynamic factor models above is essentially a statistical concept to which it is difficult to attach much economic meaning. Unlike the economic or cost-of-living approach to inflation measurement, no substantive economic theory is used to derive these estimates of core inflation. The motivation is usually some simple variant of the quantity theory of money, whereby a given change in the stock of base money is presumed to affect all prices equiproportionately (see previous quotation from Jevons). Thus, the best estimate of monetary inflation is whatever best estimates this average or common component in price changes. Bryan and Cecchetti (1994) do evaluate their measures of core inflation using basic propositions from monetary theory (core inflation should be caused by but not cause money growth, and core inflation should help to forecast future headline inflation). However these ex post evaluations of the performance of various proposed measures are not quite the same thing as using monetary theory to construct a measure of inflation. If there is a meaningful distinction between the cost of living and monetary inflation that is of concern to central bankers, then presumably we should be able to draw on monetary theory to help us measure this alternative concept of inflation.

This is the approach adopted by Quah and Vahey (1995), who adopt a more monetarytheoretic approach to the measurement of core inflation. They define core inflation as the component of measured inflation that has no impact on real output in the long run and motivate this definition on the basis of a vertical long-run 
Phillips curve. Their measure is constructed by placing long-run restrictions on a bivariate VAR system for output and inflation. Quah and Vahey assume that both output and inflation have stochastic trends, but are not cointegrated. Thus they write their system in terms of output growth and the change in the inflation rate:

$$
Z_{t}=\left[\begin{array}{c}
\Delta Y_{t} \\
\Delta \Pi_{t}
\end{array}\right]=\sum_{j=0}^{\infty} D(j) \eta(t-j),
$$

where $\eta=\left[\eta_{1}, \eta_{2}\right]^{\prime}$ with the disturbances assumed to be pairwise orthogonal and $\operatorname{Var}(\eta)=1$. Here $\Pi_{t}$ denotes inflation at date $t$ as measured by a conventional price index such as the CPI or the retail price index (RPI). Note that Quah and Vahey do not use any information on the cross-section distribution of individual price changes to construct their core inflation measure. The long-run output neutrality restriction is

$$
\sum_{j=0}^{\infty} d_{11}(j)=0 .
$$

The inflation process can be written

$$
\Delta \Pi_{t}=\sum_{j=0}^{\infty} d_{21}(j) \eta_{1}(t-j)+\sum_{j=0}^{\infty} d_{22}(j) \eta_{2}(t-j) .
$$

Quah and Vahey's candidate measure of changes in core inflation is simply

$$
\sum_{j=0}^{\infty} d_{21}(j) \eta_{1}(t-j)
$$

The Quah and Vahey approach to measuring core inflation has also been implemented by Fase and Folkertsma (1996), Claus (1997), Jacquinot (1998), Gartner and Wehinger (1998), and Álvarez and Matea (1998). Fase and Folkertsma relate this measure of inflation to Carl Menger's concept of the inner value of money. ${ }^{25}$ However, rather than

\footnotetext{
${ }^{25}$ Menger drew a distinction between the outer value ("äußerer Tauschwert") and the inner value ("innerer Tauschwert") of a commodity. The former is defined as the price of the commodity in equilibrium. The outer value of money is the purchasing power of money, i.e., the basket of goods that can be obtained for one unit of money. The outer value of money can thus be measured by an index such as the CPI. A change in the inner value of a commodity is a change that comes about because of a change in factors affecting that commodity alone. A change in the inner value of money is
}

measuring the inflation rate using the CPI, they take as their measure the unweighted average rate of change of the component series, calculated on the basis of 200 component price series for the Netherlands, arguing that "weighting may certainly be useful but there is no clear reason to gauge inflation [as a monetary phenomenon] by way of weighting." Fase and Folkertsma also calculate a core inflation measure for the EU by aggregating price and output data for Austria, Belgium, France, Germany, Italy, the Netherlands, Spain, Sweden, and the United Kingdom.

As noted, the theoretical justification for the Quah-Vahey approach is the presumption that the Phillips curve is vertical in the long run. Although this might appear to be a relatively innocuous assumption, on reflection it is clear that it is not without problems. If we accept that the Phillips curve is indeed vertical in the long run, we are essentially saying that inflation is neutral in its effects on the real economy. ${ }^{26}$ It is not obvious that all monetary economists would accept this proposition-and still fewer central bankers charged with the pursuit of price stability. Even fully anticipated constant inflation can have real effects, as documented in the well-known study by Fischer and Modigliani (1978). More generally, insofar as inflation constitutes a tax on holdings of base money, changes in this tax rate may be expected to have implications for agents' decisions about how much money to hold, which will in turn have other real effects (except under limiting assumptions). Another way of thinking about this problem is in terms of the widely held view that the sole objective of monetary policy should be price stability. ${ }^{27}$ If we accept that core inflation as measured by Quah and Vahey does in fact correspond to the component of inflation that is under the control of the monetary authority, and also that this component of inflation is in fact neutral with respect to output in the long run, it invites the question of why a central bank would

\footnotetext{
thus a price change that is due to monetary factors alone: a decline in the inner value of money will be reflected in an equiproportionate increase in all prices.

${ }^{26}$ The price level is superneutral.

${ }^{27}$ Although not universally: see, for example, Aiyagari (1990).
} 
ever want to be concerned about price stability. After all, if all the central bank controls is the price level in the long run, and if the rate at which the price level increases has no implications for the level of real economic activity, then one inflation rate is just as good in welfare terms as another. There is no reason to prefer a steady-state inflation rate of 2 percent over one of, say, 20 percent. Price stability or zero inflation ought not to play any particular role in the setting of objectives for monetary policy. Of course, nobody seriously believes this. A more realistic assumption might be that the Phillips curve is not vertical in the long run, but rather upward sloping, from left to right, as proposed by Friedman (1977). Such an assumption would better capture the notion that steady-state or long-run inflation is indeed costly from society's perspective, but would probably be a lot more difficult to operationalize.

Blix (1995) also implements the Quah and Vahey model. However Blix's implementation of the model differs in important respects from Quah and Vahey's. To start with, the long-run identifying restriction is implemented in a common trends framework rather than a VAR. That is, the model estimated is

$$
\left(\begin{array}{l}
Y_{t} \\
P_{t}
\end{array}\right)=x_{0}+\left(\begin{array}{cc}
\alpha_{11} & 0 \\
\alpha_{21} & \alpha_{22}
\end{array}\right)\left(\begin{array}{l}
r_{t} \\
n_{t}
\end{array}\right)+\Phi(L)\left(\begin{array}{l}
\varphi_{r, t} \\
\varphi_{n, t}
\end{array}\right),
$$

with the growth terms given by the vector random walk process

$$
\left(\begin{array}{c}
r_{t} \\
n_{t}
\end{array}\right)=\mu+\left(\begin{array}{l}
r_{t-1} \\
n_{t-1}
\end{array}\right)\left(\begin{array}{l}
\varphi_{r, t} \\
\varphi_{n, t}
\end{array}\right) .
$$

However, the most substantive difference between this specification and that of Quah and Vahey is the fact that the system is specified in terms of output and the price level rather than the inflation rate. ${ }^{28}$ Arguably, the proposition that changes in the money stock (and by extension in the price level) are neutral in their effects on real economic

\footnotetext{
${ }^{28}$ As justification, Blix notes that "Dickey-Fuller tests suggest that the vector $\Delta \mathrm{x}_{t}=\left(\Delta Y_{t}, \Delta P_{t}\right)^{\prime}$ is stationary for all countries considered" including the United Kingdom. Quah and Vahey claim that "the standard tests confirm that measured inflation and output can be treated as I(1)" (emphasis added) using U.K. data. There is a puzzling inconsistency here.
}

activity is less controversial than the proposition that changes in the growth rate of the money stock (and by extension the inflation rate) are also neutral in the long run. The distinction is important. Estimating core inflation on the basis of posited neutrality of changes in the price level is surely a lot more appealing from a central banker's perspective than estimation based on the long-run neutrality of inflation.

Quah and Vahey express agnosticism about the exact determinants of underlying inflation. However, Blix extends the Quah and Vahey framework to make the role of money even more explicit by estimating the following extended system:

$$
\left(\begin{array}{l}
Y_{t} \\
P_{t} \\
M_{t}
\end{array}\right)=x_{0}+\Xi_{0}\left(\begin{array}{cc}
\alpha_{11} & 0 \\
\alpha_{21} & \alpha_{22}
\end{array}\right)\left(\begin{array}{l}
r_{t} \\
n_{t}
\end{array}\right)+\Phi(L)\left(\begin{array}{l}
\varphi_{r, t} \\
\varphi_{m, t} \\
\varphi_{p, t}
\end{array}\right) .
$$

In addition, a cointegration restriction is imposed that requires that velocity (i.e., $Y_{t}+P_{t}-M_{t}$ ) is stationary. The restriction requires that

$$
\Xi_{0}=\left(\begin{array}{ll}
1 & 0 \\
0 & 1 \\
1 & 1
\end{array}\right)
$$

This extension thus brings further hypotheses about real and nominal interactions to bear on the estimation of core inflation. Blix reports that the measures of core inflation obtained in the basic and the extended forms of the Quah-Vahey model are quite similar. Unfortunately he does not provide details of the data used. Monetary theory tells us that, under a fiat monetary standard, the price level is ultimately determined by the stock of base money outstanding relative to the demand for it. Therefore, the appropriate measure of $M$ in the system above is a measure of the base money stock. However, the assumption of stationary velocity of base money is probably at odds with the data for several, if not all, industrialized countries.

Blix's approach to estimating core inflation is more plausible in many respects than the original Quah-Vahey implementation; yet, it is still limited by the fundamental problem of what can be achieved by means of long-run restrictions 
when we have only a finite sample of data available. Faust and Leeper (1997) and Cooley and Dwyer (1998) explore this problem in some detail. The latter provide a series of compelling examples that demonstrate how sensitive inferences from structural VAR models are to seemingly innocuous auxiliary assumptions (about whether the data are trend stationary or difference stationary, the number of underlying shocks, etc.). So far there has been no attempt to evaluate the sensitivity of core inflation estimates from the structural VAR approach of Quah and Vahey to alternative auxiliary assumptions. This approach to core inflation estimation is also subject to the criticism levied against the DFI: that, because it is based on econometric estimates, history will change each time a new observation is added.

\section{CONCLUDING OBSERVATIONS}

This paper has reviewed various approaches to the measurement of core inflation. A common theme linking many of these approaches is that there is some concept of monetary inflation that is distinct from changes in the cost of living and that is a more appropriate target of monetary policy. From a traditional quantity theory perspective, this theme has motivated several authors to look at alternative estimates of the central tendency of the distribution of prices as the best estimate of core or monetary inflation. Other authors have used dynamic frameworks along with neutrality propositions from monetary theory to try to estimate core inflation. All of these approaches suffer from this fact: There is simply no agreed upon theory of money that can serve as a basis for inflation measurement that could plausibly replace the theory of the cost of living.

I have also addressed (somewhat tangentially) the question of how measures of core inflation ought to be evaluated. Many of the measures of core inflation that have been proposed in recent years eschew the theory of the cost-of-living index as the basis for measurement. This makes evaluation difficult. The theory of the cost-of-living index provides a coherent framework for the evaluation of measures of headline inflation such as the CPI or the HICP. ${ }^{29}$ Essentially we deem a measure of headline inflation to be reliable by the degree to which it approximates the theoretical ideal. There is no theoretical ideal for a monetary measure of core inflation. Rather it is evaluated by its consistency with various loosely formulated propositions from monetary theory. Thus, a measure of core inflation that is designed to capture "monetary" inflation might be evaluated by the extent to which it is (Granger) caused by some measure of the money stock but does not (Granger) cause money. Or a measure might be evaluated by the degree to which it forecasts future inflation, which is an approach suggested by Blinder (1997). The problem with this is that we start to leave the area of economic measurement and enter the domain of formal theorizing and forecasting. It needs to be asked why we would want a measure of core inflation that forecasts future headline inflation. Surely the central bank would be more interested in forecasting future inflation (and would get better results) using multivariate rather than univariate approaches?

This review of various approaches to core inflation measurement also suggests a large number of questions for future research.

First and foremost, before choosing a measure of core inflation we need to specify what it is we want the measure for. Do we want a measure of core inflation to answer the question "What would the inflation rate have been if oil prices (or indirect taxes) had not increased last month?" If so, then none of the approaches reviewed above will help. This question can be answered only in the context of a full general equilibrium model of the economy. Furthermore, if the measure of inflation we are interested in is the cost of living, then it is not clear why we would ever want to exclude the effects of oil price increases or indirect taxes. Thus it must be the case that when measuring core inflation we have some other inflation concept in mind. Ideally, a central bank would be most interested in a measure of inflation that measured the rate of decline in the purchasing power of money. Unfortunately there is no well-

\footnotetext{
${ }^{29}$ Although, as noted earlier, the HICP uses household final monetary consumption rather than the cost of living as its price concept.
} 
developed and generally agreed upon theory that can serve as a guide to constructing such a measure. Thus, in practical terms, we are left with the options of (i) constructing a core inflation measure so as to better track the trend inflation rate (somehow defined) in real time or (ii) forecast the future headline inflation rate, which in many circumstances may amount to the same thing.

The discussion above was highly critical of the various dynamic approaches to core inflation measurement, such as the DFI and the structural VAR approach of Quah and Vahey. I asserted that the major shortcoming of the DFI model is that history changes each time a new observation is added. It would be useful to know before dismissing this approach completely by how much history changes each time the model is reestimated. This should also be done for the other econometricbased measures of core inflation. If it turns out that the amount by which the addition of new information causes previous estimates of core inflation to change is trivial, this criticism might lose a lot of its force. There would also be some merit in further exploring the structural VAR approach of Quah and Vahey. The great merit of this approach is that it has some basis in monetary theory, but it makes sense only if it is operationalized on the basis of neutrality of money rather than superneutrality. Here what needs to be done (in addition to assessing the sensitivity of estimates to the addition of new information) is to see how sensitive the measures of core inflation are to violations of the auxiliary assumptions.

\section{REFERENCES}

Aiyagari, S. Rao. "Deflating the Case for Zero Inflation.” Federal Reserve Bank of Minneapolis Quarterly Review, Summer 1990, 14(3), pp. 2-11.

Álvarez, Luis Julián and de los Llanos Matea, Mariá. "Measures of the Inflation Process," in Jose Luis Malo De Molina, ed. Monetary Policy and Inflation in Spain. London: Palgrave Macmillan, 1998.

Angelini, Elena; Henry, Jérôme and Mestre, Ricardo. "A Multi-Country Trend Indicator for Euro Area Inflation: Computation and Properties." Working Paper No. 60, European Central Bank, 2001a.
Angelini, Elena; Henry, Jérôme and Mestre, Ricardo. "Diffusion Index-Based Inflation Forecasts for the Euro Area.” Working Paper No. 61, European Central Bank, 2001b.

Apel, Mikael and Jansson, Per. "A Parametric Approach for Estimating Core Inflation and Interpreting the Inflation Process." Working Paper No. 80, Sveriges Riksbank, 1999.

Australian Bureau of Statistics. Information Paper: Introduction of the 14th Series Australian Consumer Price Index, ABS Catalogue No. 6456.0. Canberra: Australian Bureau of Statistics, 2000.

Bakhshi, Hasan and Yates, Anthony. "To Trim or Not To Trim? An Application of a Trimmed Mean Inflation Estimator to the United Kingdom." Working Paper No. 97, Bank of England, 1999.

Ball, Laurence and Mankiw, N. Gregory. "Relative Price Changes as Aggregate Supply Shocks." Quarterly Journal of Economics, 1995, 110(1), pp. 161-93.

Balke, Nathan S. and Wynne, Mark A. "An Equilibrium Analysis of Relative Price Changes and Inflation." Journal of Monetary Economics, April 2000, 45(2), pp. 269-92.

Bank of Canada. “Targets for Reducing Inflation: Further Operational and Measurement Considerations." Bank of Canada Review, September 1991, pp. 3-23.

Bank of Canada. Renewal of the Inflation-Control Target: Background Information-November 2006. Ottawa: Bank of Canada.

Bank of England. Inflation Report. London: Bank of England, various years.

Bank of Japan. "The Introduction of a New Framework for the Conduct of Monetary Policy." Press release, March 9, 2006.

Bean, Charles. Commentary on "Impact of Globalization on Monetary Policy" at a symposium sponsored by the Federal Reserve Bank of Kansas City, “The New Economic Geography,” Jackson Hole, 
Wyoming, August 24-26, 2006;

http://www.kansascityfed.org/PUBLICAT/SYMPOS/ 2006/PDF/Bean.paper.0822.pdf.

Beaton, Roger and Fisher, Paul. "The Construction of RPIY.” Working Paper No. 28, Bank of England, 1995.

Bernanke, Ben S.; Laubach, Thomas; Mishkin, Frederic S. and Posen, Adam S. Inflation Targeting: Lessons from the International Experience. Princeton: Princeton University Press, 1999.

Blinder, Alan S. "The Consumer Price Index and the Measurement of Recent Inflation." Brookings Papers on Economic Activity, 1980, 2, pp. 539-65.

Blinder, Alan S. "Review of Core Inflation by Otto Eckstein." Journal of Political Economy, 1982, 90, pp. 1306-09.

Blinder, Alan S. "Measuring Short-Run Inflation for Central Bankers: Commentary.” Federal Reserve Bank of St. Louis Review, May/June 1997, 79(3), pp. 157-60.

Blix, Mårten. "Underlying Inflation: A Common Trends Approach.” Working Paper No. 23, Sveriges Riksbank, 1995.

Board of Governors of the Federal Reserve System. Federal Reserve Act And Other Statutory Provisions Affecting the Federal Reserve System (As Amended Through August 1990). Washington DC: Board of Governors of the Federal Reserve System, 1990.

Board of Governors of the Federal Reserve System. Monetary Policy Report to the Congress, Federal Reserve Bulletin, 2000, 86, pp. 161-87.

Bowley, A.L. "Notes on Index Numbers." Economic Journal, 1928, 38(150), pp. 216-37.

Brischetto, Andrea and Richards, Anthony. "The Performance of Trimmed Mean Measures of Underlying Inflation." Research Discussion Paper No. RDP2006-10, Reserve Bank of Australia, 2006.

Bryan, Michael F. and Cecchetti, Stephen G. "The Consumer Price Index as a Measure of Inflation." Federal Reserve Bank of Cleveland Economic Review, Fourth Quarter 1993, 29(4), pp. 15-24.
Bryan, Michael F. and Cecchetti, Stephen G. "Measuring Core Inflation," in N. Gregory Mankiw, ed., Monetary Policy. Chicago: University of Chicago Press, 1994, pp. 195-215.

Bryan, Michael F. and Cecchetti, Stephen G. "Inflation and the Distribution of Price Changes." NBER Working Paper No. 5793, National Bureau of Economic Research, 1996.

Bryan, Michael F.; Cecchetti, Stephen G. and Wiggins, Rodney L. II. "Efficient Inflation Estimation.” NBER Working Paper No. 6183, National Bureau of Economic Research, 1997.

Bryan, Michael F. and Pike, Christopher J. "Median Price Changes: An Alternative Approach to Measuring Current Monetary Inflation.” Federal Reserve Bank of Cleveland Economic Commentary, December 1, 1991.

Callahan, David W. "Defining the Rate of Underlying Inflation.” Monthly Labor Review, September 1981, 104(9), pp. 16-19.

Cassino, Vincenzo. "The Distribution of Price and Wage Changes in New Zealand.” Discussion Paper Series G95/6, Reserve Bank of New Zealand, 1995.

Cecchetti, Stephen G. "Measuring Inflation for Central Bankers." Federal Reserve Bank of St. Louis Review, May 1997, 79(3), pp. 143-55.

Clark, Todd E. "Comparing Measures of Core Inflation.” Federal Reserve Bank of Kansas City Economic Review, Second Quarter 2001, 86(2), pp. 5-31.

Claus, Iris. "A Measure of Underlying Inflation for the United States.” Working Paper No. 97-20, Bank of Canada, 1997.

Clements, Kenneth W. and Izan, H.Y. "A Note on Estimating Divisia Index Numbers." International Economic Review, October 1981, 22(3), pp. 745-47.

Clements, Kenneth W. and Izan, H.Y. "The Measurement of Inflation: A Stochastic Approach." Journal of Business and Economic Statistics, July 1987, 5(3), pp. 339-50. 
Cogley, Timothy. "A Simple Adaptive Measure of Core Inflation." Journal of Money, Credit, and Banking, 1998, 34(1), pp. 94-113.

Commission of the European Communities. Report from the Commission to the Council: On the Harmonization of Consumer Price Indices in the European Union. Brussels: Commission of the European Communities, 1998.

Cooley, Thomas F. and Dwyer, Mark. "Business Cycle Analysis Without Much Theory: A Look at Structural VARs." Journal of Econometrics, April 1998, 83(1-2), pp. 57-88.

Cutler, Joanne. "Core Inflation in the UK.” External MPC Discussion Paper No. 3, Bank of England, 2001.

Diewert, W. Erwin. "On the Stochastic Approach to Index Numbers." Department of Economics Discussion Paper No. 95/31, University of British Columbia, 1995.

Diewert, W. Erwin. "Alternative Strategies for Aggregating Prices in the Consumer Price Index: Commentary.” Federal Reserve Bank of St. Louis Review, May/June 1997, 79(3), pp. 127-37.

Diewert, W. Erwin and Bossons, John. "Adjusting the Consumer Price Index for Changes in Taxes." Discussion Paper No. 87-09, University of British Columbia, 1987.

Diewert, W. Erwin and Fox, Kevin J. "The Measurement of Inflation after Tax Reform." Discussion Paper No. 98-05, University of British Columbia, 1998.

Donkers, H.W.; Jensen, J. Bjerregaard; Hyrkkö, J.; Lehtinen, I.; Murphy, D.C.; Stolpe, G. and Turvey, R. "Adjusting the CPI for Indirect Taxes." Bulletin of Labor Statistics, 1983, 4, pp. 26-30.

Dow, James P. Jr. "Measuring Inflation Using Multiple Price Indexes." Unpublished manuscript, Department of Economics, University of CaliforniaRiverside, 1994.

Eckstein, Otto. Core Inflation. New York: Prentice Hall, 1981.
European Commission. "On Harmonization of Consumer Price Indices in the European Union," Catalogue No. CB-CO-98-133-EN-C, 1998.

Fase, M.M.G. and Folkertsma, C.K. "Measuring Core Inflation: An Attempt To Operationalise Carl Menger's Concept of the Inner Value of Money." Staff Report No. 8, De Nederlandsche Bank, 1996.

Faust, Jon and Leeper, Eric M. "When Do Long-Run Identifying Assumptions Give Reliable Results?" Journal of Business and Economic Statistics, July 1997, 15(3), pp. 345-53.

Fisher, Irving. The Purchasing Power of Money: Its Determination and Relation to Credit, Interest and Crises. New York: Macmillan, 1920.

Fischer, Stanley and Modigliani, Franco. "Towards an Understanding of the Real Effects and Costs of Inflation." Weltwirtschaftliches Archiv, 1978, 114, pp. 810-33.

Friedman, Milton. "Nobel Lecture: Inflation and Unemployment." Journal of Political Economy, June 1977, 85(3), pp. 451-72.

Gartner, Christine and Wehinger, Gert D. "Core Inflation in Selected European Union Countries." Working Paper No. 33, Oesterreichische Nationalbank, 1998.

Giannone, Domenico and Matheson, Troy. "A New Core Inflation Indicator for New Zealand.” Discussion Paper DP2006/10, Reserve Bank of New Zealand, December 2006.

Giavazzi, Francesco and Mishkin, Frederic S. An Evaluation of Swedish Monetary Policy Between 1995 and 2005. Stockholm: Riksdagstryckeriet, 2006.

Hodrick, Robert J. and Prescott, Edward C. "Post-War U.S. Business Cycles: An Empirical Investigation.” Journal of Money, Credit, and Banking, February 1997, 29(1), pp. 1-16.

Hogan, Seamus; Johnson, Marianne and Laflèche, Thérèse. "Core Inflation.” Technical Report No. 89, Bank of Canada, 2001. 
Howitt, Peter. “Alternative Strategies for Aggregating Prices in the CPI: Commentary.” Federal Reserve Bank of St. Louis Review, May/June 1997, 79(3), pp. 139-41.

Jacquinot, Pascal. "L'Inflation Sous-jacente a Partir d'une Approche Structurelle des VAR: Une Application a la France, l'Allemagne et au RoyaumeUni.” Notes D’Études et De Recherche NER No. 51, Banque de France, 1998.

Jevons, W.S. "Variations in Prices and the Value of Currency since 1762." Journal of the Royal Statistical Society, 1865, 28, pp. 294-325.

Kearns, Jonathan. "The Distribution and Measurement of Inflation.” Research Discussion Paper 9810, Reserve Bank of Australia, 1998.

Keynes, John Maynard. A Treatise on Money. London: Macmillan, 1930.

Khettry, N. Neil K. and Mester, Loretta J. "Core Inflation as a Predictor of Total Inflation.” Federal Reserve Bank of Philadelphia Research RapSpecial Report, April 26, 2006.

Laflèche, Thérèse. "Statistical Measures of the Trend Rate of Inflation.” Bank of Canada Review, Autumn 1997, pp. 29-47.

McElhattan, Rose. “Underlying Inflation.” Federal Reserve Bank of San Francisco Weekly Letter, April 2, 1982.

Morana, Claudio. "Measuring Core Inflation in the Euro Area.” Working Paper No. 36, European Central Bank, 2000.

Motley, Brian. "Should Monetary Policy Focus on 'Core' Inflation?” Federal Reserve Bank of San Francisco Economic Letter, April 18, 1997, pp. 97-111.

Nessén, Marianne and Söderström, Ulf. "Core Inflation and Monetary Policy." Working Paper No. 110, Sveriges Riksbank, 2000.

Parkin, Michael. "On Core Inflation by Otto Eckstein: A Review Essay." Journal of Monetary Economics, September 1984, 14(2), pp. 251-64.
Peach, Richard W. and Alvarez, Karen. "Core CPI: Excluding Food, Energy....and Used Cars?” Federal Reserve Bank of New York Current Issues in Economics and Finance, April 1996, 2(4).

Quah, Danny and Vahey, Shawn P. "Measuring Core Inflation." Working Paper No. 31, Bank of England, 1995; also Economic Journal, September 1995, 105(432), pp. 1130-44.

Reis, Ricardo and Watson, Mark W. "Relative Goods' Prices and Pure Inflation.” NBER Working Paper No. 13615, National Bureau of Economic Research, 2007.

Reserve Bank of Australia. "Measuring Underlying Inflation.” Reserve Bank of Australia Bulletin, August 1994.

Reserve Bank of Australia. "Statement on the Conduct of Monetary Policy.” Canberra: Reserve Bank of Australia, 1996.

Reserve Bank of Australia. "The Implications of Recent Changes to the Consumer Price Index for Monetary Policy and the Inflation Target.” Reserve Bank of Australia Bulletin, October 1998, pp. 1-5.

Reserve Bank of New Zealand. Policy Targets Agreement (March 1990). Wellington: Reserve Bank of New Zealand, 1990.

Reserve Bank of New Zealand. Policy Targets Agreement (1997). Wellington: Reserve Bank of New Zealand, 1997a.

Reserve Bank of New Zealand. "Background Note for Journalists and Analysts on the New Policy Targets Agreement, and the Consequential Decision to Discontinue the Calculation and Publication of 'Underlying Inflation.'” Wellington: Reserve Bank of New Zealand, 1997b.

Reserve Bank of New Zealand. Monetary Policy Statement: November 1999. Wellington: Reserve Bank of New Zealand, 1999.

Rich, Robert W. and Steindel, Charles. "A Review of Core Inflation and an Evaluation of Its Measures." Federal Reserve Bank of New York Economic Policy Review, 2005, 13, pp. 19-38. 
Richards, Anthony J. "Measuring Underlying Inflation." Reserve Bank of Australia Bulletin, December 2006.

Roberts, Ivan. "Underlying Inflation: Concepts, Measurement and Performance." Research Discussion Paper No. RDP2005-05, Reserve Bank of Australia, 2005.

Roger, Scott. "Measures of Underlying Inflation in New Zealand, 1981-95.” Discussion Paper No. G95/5, Reserve Bank of New Zealand, 1995.

Roger, Scott. "A Robust Measure of Core Inflation in New Zealand, 1949-96.” Discussion Paper No. G97/7, Reserve Bank of New Zealand, 1997.

Roger, Scott. "Core Inflation: Concepts, Uses and Measurement." Discussion Paper G98/9, Reserve Bank of New Zealand, 1998.

Scadding, John L. "Estimating the Underlying Inflation Rate." Federal Reserve Bank of San Francisco Economic Review, Spring 1979, pp. 7-18.

Schreder, Harold X. "Impact of Business Conditions on Investment Policies." Journal of Finance, May 1952, 7(2), pp. 138-73.

Shiratsuka, Shigenori. “Core Indicators of Japan's Consumer Price Index." Bank of Japan Review, November 2006, pp. 1-9.

Smith, Julie K. "Better Measures of Core Inflation?" Paper presented at the Federal Reserve Bank of Dallas / Federal Reserve Bank of Cleveland Conference on Price Measurement for Monetary Policy, Dallas, May 24-25, 2007.
Sprinkel, Beryl W. "1975: A Year of Recession, Recovery and Decelerating Inflation." Journal of Business, January 1975, 48(1), pp. 1-4.

Stevens, Glenn R. "Six Years of Inflation Targeting." Reserve Bank of Australia Bulletin, May 1999, pp. 46-61.

Selvanathan, E.A. and Prasada Rao, D.S. Index Numbers: A Stochastic Approach. Ann Arbor: University of Michigan Press, 1994.

Tobin, James. "The Monetarist Counter-Revolution Today-An Appraisal.” Economic Journal, March 1981, 91(361), pp. 29-42.

U.S. Department of Labor: Bureau of Labor Statistics. BLS Handbook of Methods, Washington, DC: Government Printing Office, 1997.

Vega, Juan-Luis, and Wynne, Mark A. "An Evaluation of Some Measures of Core Inflation for the Euro Area." German Economic Review, 2003, 4, pp. 269-306.

Vining, Daniel R. Jr. and Elwertowski, Thomas C. "The Relationship Between Relative Prices and the General Price Level.” American Economic Review, September 1976, 66(4), pp. 699-708.

Wynne, Mark A. "Measuring Short-Run Inflation for Central Bankers: Commentary.” Federal Reserve Bank of St. Louis Review, May/June 1997, 79(3), pp. 161-67.

Wynne, Mark A. "Core Inflation: A Review of Some Conceptual Issues.” Working Paper No. 5, European Central Bank, 1999. 